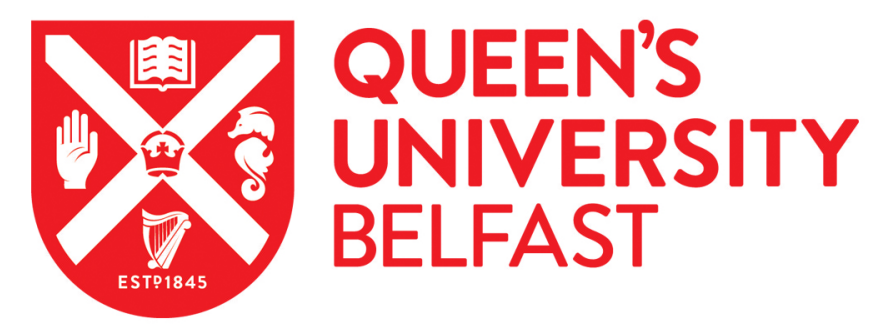

\title{
De Jure and de Facto Determinants of Power: Evidence from Mississippi
}

Bertocchi , G., \& Dimico, A. (2017). De Jure and de Facto Determinants of Power: Evidence from Mississippi. Constitutional Political Economy, 28(4), 321-345. https://doi.org/10.1007/s10602-017-9239-9

\section{Published in:}

Constitutional Political Economy

\section{Document Version:}

Peer reviewed version

Queen's University Belfast - Research Portal:

Link to publication record in Queen's University Belfast Research Portal

\section{Publisher rights}

(C) 2017 Springer Science+Business Media New York.

This work is made available online in accordance with the publisher's policies. Please refer to any applicable terms of use of the publisher.

\section{General rights}

Copyright for the publications made accessible via the Queen's University Belfast Research Portal is retained by the author(s) and / or other copyright owners and it is a condition of accessing these publications that users recognise and abide by the legal requirements associated with these rights.

Take down policy

The Research Portal is Queen's institutional repository that provides access to Queen's research output. Every effort has been made to ensure that content in the Research Portal does not infringe any person's rights, or applicable UK laws. If you discover content in the Research Portal that you believe breaches copyright or violates any law, please contact openaccess@qub.ac.uk. 


\title{
De Jure and de Facto Determinants of Power: Evidence from Mississippi ${ }^{\#}$
}

\author{
Graziella Bertocchi* \\ Arcangelo Dimico**
}

December 2016

\# We would like to thank three anonymous referees and workshop participants at ECINEQ, Delhi Annual Conference on Economic Growth and Development, Asian Meetings of the Econometric Society, PRIN Workshop on Institutions, Social Dynamics and Economic Development, Singapore Management University, Tufts University, Boston University, New York University, Brown University, and USI Lugano, for helpful comments on previous drafts. Generous financial support from Fondazione Cassa di Risparmio di Modena and the Italian University Ministry is gratefully acknowledged.

* Corresponding author. Affiliations: University of Modena and Reggio Emilia, CEPR and IZA - Address: Dipartimento di Economia Marco Biagi, Viale Berengario, 51, I-41121 Modena, Italy - Phone: +39 0592056856 - E-mail: graziella.bertocchi@unimore.it - Webpage: http://www.economia.unimore.it/bertocchi_graziella.

** Affiliation: Queen's University Belfast - Address: Management School, Riddel Hall, 185, Stranmillis Road, Belfast, BT9 5EE, UK- Phone: +44 02890974176 - E-mail: a.dimico@qub.ac.uk -Webpage: https://sites.google.com/site/arcangelodimico. 


\begin{abstract}
We evaluate the empirical effectiveness of de facto versus de jure determinants of political power in the U.S. South between the end of the nineteenth and the beginning of the twentieth century. Using previously-unexploited racially-disaggregated data on voter registration in Mississippi for the years 1896 and 1899, we show that the observed pattern of black political participation is driven by de facto disfranchisement as captured by the presence of a black political majority, which negatively affects black registration. The de jure provisions introduced with the 1890 state constitution and involving literacy tests and poll taxes exert a non-robust impact. Furthermore, a difference-in-differences approach shows that the decline in aggregate turnout pre-dates the introduction of de jure restrictions and confirms a causal effect of the presence of a black political majority. De jure restrictions intensify the influence of the latter after 1890, which suggests that the main effect of the constitutional reforms may have been an institutionalization of de facto disfranchisement.
\end{abstract}

JEL Codes: J15, N41, O43, P16.

Key words: Race, voting, disfranchisement, Mississippi 1890 constitution, institutions. 


\section{Introduction}

Recent advances in comparative development have investigated the determinants and the influence of institutions. In order to understand the coexistence of change and persistence in institutional dynamics, a distinction has been drawn between de jure and de facto sources of political power (Acemoglu and Robinson, 2008a,b). De facto (i.e., real) power is power that is not allocated by de jure (i.e., legal) institutions such as voting legislation or elections, but rather is possessed by a social group as a result of wealth, violence, or other means.

In the context of the antebellum U.S. South, during the times that witnessed a restoration of white supremacy - following the Civil War, the abolition of slavery, and the Reconstruction Era - de jure power took the form of suffrage restrictions, while de facto control reflected the interracial conflict between the white elites and the black descendants of slaves. The goal of this paper is to investigate empirically the relative strength of these alternatives although interrelated sources of power. In order to do so, we employ previously-unexploited, raciallydisaggregated data on voter registration at the end of the nineteenth century for the state of Mississippi. These data represent a unique source of information on voter registration by race at the county level, which can complement the information contained in aggregated countylevel voter-turnout data.

Our analysis provides answers for still-open questions concerning the effect of the laws introduced by southern U.S. states between the end of the nineteenth and the beginning of the twentieth century with the aim of disfranchising a large share of the population. The majority of these laws took the form of poll taxes and literacy tests which prevented poor and illiterates from casting their vote by introducing barriers to voter registration. African Americans and poor whites were the main target of these rules. In fact, by ensuring their support to the Republican and Populist parties these groups represented a serious threat to the aspirations of the wealthy white landowners who were in those days mainly represented by the Democratic party. In order to insulate the political system from these challenges to their hegemony, white Democrats introduced barriers to voting meant to exclude the majority of blacks and poor whites from the southern electorate.

The effectiveness of voting restrictions in the antebellum South is debated in an early, historical literature. While some scholars believe in an effective power of the de jure disfranchisement schemes in restricting electorate suffrage (e.g., Kousser, 1974), others forcefully question it (e.g., Bond, 1934, 1939; Key, 1949; Ogden, 1958). According to Key’s "fait accompli" hypothesis, de jure disfranchisement is the result of a condition of de facto 
disfranchisement - mainly grounded on race - which restricted the electorate even before these laws were passed. Accordingly, the white elite was able to push these laws through the assemblies only because political participation had already been suppressed through the use of extra-legal force, violence, and intimidation, and because of the growing hegemony of the white plantation elite represented by Democrats. The feeling that such a state of violence and fraud could not be perpetuated for long and the increasing abuse of power in public office led to the passage in state constitutions of de jure procedures (Wharton, 1947).

In order to compare the relative explanatory power of de jure versus de facto drivers of disfranchisement, we need measures for the latter. The literature in the field (in particular Kousser, 1974; Key, 1949; and Ogden, 1958) agrees in pointing to the racial composition of the local eligible population as an effective proxy, since the opposition to black registration was systematically tougher in counties where blacks represented the majority. For instance, Wharton (1947) reports that, except in counties where white Democrats had a safe majority, blacks were strenuously pressured to refrain from voting, or even to vote the Democratic ticket, both through economic means (such as threats of unemployment) and other cooptative or intimidative practices.

The contribution of this paper is to provide evidence on the relative importance of de facto and de jure political power in the state of Mississippi. Mississippi represents an ideal starting point for such an investigation. In socioeconomic terms, the state is indeed a striking image of the South in the time period of interest and beyond. In the past, it had one the highest proportion of slaves ${ }^{1}$ (almost 52 percent in 1860, third after South Carolina and Louisiana), followed by an equally high proportion of blacks over population in 1890. In 2000 it still had the highest proportion of blacks (37 percent, if we exclude the District of Columbia with 60 percent). The state was one of the first to enact de jure disfranchisement provisions in 1890. Moreover, in economic terms, it has always been one of the poorest states of the U.S., with the lowest income per capita $(\$ 15,853)$ in 2000.

Prior to the Civil War, blacks in Mississippi were denied the right to vote by express provision of law. After the War, they were first permitted to vote under state law, on the same basis as whites, with the 1869 constitution. As reported by the U.S. Commission on Civil Rights (1965), the peak of black political participation occurred between 1870 and 1873 while white opposition began to organize in 1875 counting, at least initially, on intimidation, violence, and

\footnotetext{
${ }^{1}$ In 1860 there were fewer than 1,000 free people of colour.
} 
fraud. Later on, however, the Democratic party pushed for the introduction of formal restrictions through a new constitution. In 1890 the state legislature called for a convention with the task of drafting it. Due to the overwhelming power of the Democrats in the government, the convention ended up including only a single black delegate, who was also the only Republican, out of 134. Despite the presence of a marginal faction supporting the general idea of wealth and literacy qualifications to be applied uniformly to blacks and whites, the declared goal of the vast majority of delegates was to restrict the black vote to secure the supremacy of the white race (Wharton, 1947). The new constitution, enacted in November 1890, introduced two main novelties, a literacy test and a poll tax, as pre-requisites for registration. Both requirements were explicitly devised to bypass the fifteenth amendment to the U.S. constitution, which prohibits raced-based disfranchisement. In addition, the new constitution introduced longer residence requirements and the necessity of a complete re-registration before the first election following the $1^{\text {st }}$ of January $1892 .^{2}$

Our goal is to assess the effectiveness of these de jure restrictions, relative to de facto sources of power, on black political participation in Mississippi. Our empirical investigation consists of two parts.

First, we start with the analysis of pooled data from a previously-unexploited, raciallydisaggregated source of information on voter registration. These data are collected from the United States v. Mississippi Interrogatory Answers, a source of official statistics for the state of Mississippi. "The Interrogatory Answers collection is the result of a 1962 action brought by the "USA government against the State of Mississippi (...), alleging that the defendants had violated the voting rights of African American citizens. The U.S. District Court for the Southern District of Mississippi dismissed the complaint, but the Supreme Court reversed the suit on appeal in March 1965. However, Congress passed the Voting Rights Act of 1965 before the District Court reconsidered the case (...). The information outlined in the interrogatory answers provide detailed data and sources that illuminate the difficulties African Americans faced in Mississippi when they attempted to exercise their right to vote between 1890 and 1963." (University of Mississippi Libraries, Digital Collections). In particular, the Interrogatory Answers contain county-level data on voter registration for 1896 and 1899 which, unlike the

\footnotetext{
${ }^{2}$ New qualifications for voters required that "each elector (1) Be a male citizen; (2) Be twenty one years of age or over; (3) Be a resident of the State two years and of the election district or municipality one year; (4) Be registered to vote; (5) Be not disqualified by reason of insanity, idiocy, or conviction of certain crimes; (6) Be able to read any section of the State Constitution, or be able to understand it when read to him, or to a give reasonable interpretation of it; (7) Have paid all taxes by February of the year in which he desires to vote and produce evidence of payment. This includes payment of an annual poll tax of two dollars."
} 
vast majority of official statistics on political outcomes, are disaggregated by race. Therefore, they add a previously-unavailable, unique dimension to the analysis of voting patterns in this historical period. ${ }^{3}$

Our main measure of de facto power is a dummy variable which takes value one for counties where blacks represent the majority among eligible voters. This variable is meant to capture the potentially pivotal role of blacks, and therefore reflect racial conflict through the host of actions aimed at discouraging black political participation. To assess the influence of de facto determinants of power we also rely on a direct measure of racial violence represented by the frequency of lynching of blacks, as well as a proxy for the power of the white landed elite given by land inequality. Since the Interrogatory Answers data only cover the years 1896 and 1899 and thus do not provide information on the period that precedes the 1890 constitution, in order to estimate the potential influence of de jure factors we exploit the variation in the level of black literacy and wealth to gauge the effectiveness of the literacy test and the poll tax, respectively.

Our regressions results suggest that proxies for de facto disfranchisement, and in particular the presence of a black political majority, explain a large portion of the variation in the registration of blacks. The latter decreases by 9.9 percent in majority-back counties. At the same time, the effect of proxies for de jure restrictions is marginal and non-robust, as it is driven by their enforcement in majority-black counties.

In the second part of our investigation we turn to a difference-in-differences approach based on county-level aggregate voter-turnout data by Clubb, Flanigan and Zingale (2006) which, despite being unavailable by race, cover U.S. states for the period before and after the introduction of the new constitution. Exploiting the correlation between black registration and aggregate turnout, we employ these data by comparing the counties in Mississippi, the treated group, with an appropriately-selected out-of-state control group which was not exposed to de jure restrictions. Regression results confirm that the decline in turnout pre-dates the introduction of de jure restrictions. De facto drivers of disfranchisement, as captured again by the pivotal role of race in the local balance of power, play instead a major role, with the presence of a black political majority reducing turnout by 4 percent. De jure restrictions only matter in majorityblack counties, causing a more intense influence of race after 1890, which suggests that the

\footnotetext{
${ }^{3}$ In the Interrogatory Answers registration records are collected from registration books and complemented by additional information from poll books, poll tax receipts, poll tax payers lists, and application forms. Details are provided for each county.
} 
main effect of constitutional reforms may have been an institutionalization of de facto disfranchisement.

Overall, the main message emerging from our investigation can be summarized as follows: consistent with Key (1949), the process of black disfranchisement starts well before the introduction of the new constitution and disfranchisement is stronger in counties with a black political majority. However, the effect of the pivotal position of blacks in the electoral process does become more binding after 1890, which can be interpreted as supportive of Kousser (1974)'s view as well. More generally, our findings also highlight a self-reinforcing effect of informal and formal restrictions across southern states.

The rest of the paper is organized as follows. Section 2 briefly summarizes the related literature. Section 3 presents our empirical results based on the Interrogatory Answers data on registration by race. Section 4 reports difference-in-differences estimates on aggregate turnout data. Section 5 concludes and illustrates the relevance of our results for understanding the ongoing debate about electoral legislation and racial discrimination in the U.S. The Appendix contains information on data and sources as well as robustness checks.

\section{Related Literature}

A first generation of empirical contributions on the effects of suffrage restrictions in the U.S. South during the late nineteenth and the early twentieth century is based on ecological regressions. As a response to the paucity of data organized by race, this literature estimates the racial pattern of voter behavior by exploiting the variation in the racial components of the eligible population, combined with the available data on overall turnout. Despite being based on this common approach, Kousser $(1973,1974)$ strongly rejects Key’s $(1949)$ “fait accompli” hypothesis, while Redding and James (2001) do acknowledge the cumulative influence of violence and intimidation against blacks, especially in the presence of a large black population.

More recent related empirical contributions include Naidu (2012), who examines the effect of voting restrictions over the 1870-1920 period. Using adjacent county pairs of counties that straddle state boundaries, he finds that the introduction of poll taxes and literacy tests lowered overall voter turnout, increased the Democratic vote share, and reduced the teacher-child ratio in black schools. However, the potential role of competing factors such as race is not explicitly investigated. Chay and Munshi (2011) examine political participation in the U.S. South in the 1870-1890 period, that is during and just after Reconstruction, and find that the Republican vote share, which they interpret as a measure of black political mobilization, was larger in the 
presence of historical pre-conditions captured by the share of land allocated to the major plantation crops. In other words, during this historical period, which largely predates the one we focus on, a greater density of blacks allowed more social cohesion and promoted through this channel their political participation. A common feature with our findings is the prominent role of racial factors in determining electoral outcomes. Jones, Troesken and Walsh (2013) present evidence of the effects of lynching on black disfranchisement in post-Reconstruction South. While our data do confirm a correlation between lynching and black political participation, we find that lynching is not a significant driver once we control for the presence of a black political majority. ${ }^{4}$

A discussion on the relative relevance of de jure versus de facto political power is contained in Acemoglu and Robinson (2008a,b). However, their analysis is mainly theoretical and descriptive and focuses on an earlier historical period, immediately before and after the Civil War. Their general argument is that a change in political institutions that modifies the distribution of de jure power may be offset by a change in the distribution of de facto political power. In the context of the U.S. South, the abolition of slavery and the enfranchisement of blacks following the Civil War represented a huge change in the distribution of de jure power. Yet, the economic and political system changed very little if compared with the antebellum South, since the persistence of the de facto political power of landed elites was able to compensate effectively for the loss of their de jure political power. The elites managed to keep control through the continuation of the plantation economy and through intimidation and violence. ${ }^{5}$ In the present paper, we empirically test the implications for this analysis over the post-Reconstruction period. ${ }^{6}$

A complementary stream of research has examined the removal of voting restrictions following the 1965 Voting Rights Act. The conclusions are that removal of restrictions increased black registration (Alt, 1994) as well as overall turnout, with consequences for public

\footnotetext{
${ }^{4}$ A parallel stream of the literature has focused on the long-term influence of slavery and racial conflict on current economic performances, education, and inequality. See Margo (1982), Nunn (2008), and Bertocchi and Dimico (2011, 2012, 2014).

${ }^{5}$ Other general models of franchise extensions are proposed by Ades and Verdier (1996), Acemoglu and Robinson (2000), Bourguignon and Verdier (2000), and Lizzeri and Persico (2004), while Llavador and Oxoby (2005) and Galor, Moav and Vollrath (2009) offer theoretical motivations for landowners' opposition to democracy.

${ }^{6}$ A distinction between informal and formal rules is applied by Carden and Coyne (2013) to the analysis of the race riots during Reconstruction, building on the theory of the stickiness of rules (Boettke, Coyne and Leeson, 2008). Accordingly, because of lower enforcement costs formal rules are more likely to stick when they are grounded in existing informal rules. In the context of race riots there was a disjuncture between the formal rules to protect blacks and the informal norms held by whites.
} 
policy, in particular education policy (Filer, Kenny, and Morton, 1991; Cascio and Washington, 2014). ${ }^{7}$

\section{The Impact of Voter Registration Restrictions in the State of Mississippi}

After the adoption of the new constitution in 1890, black political participation in Mississippi decreased sharply. Kousser (1974) estimates that in 1888 black turnout was about 30 percent, while black registration was reduced to 5.4 and 8.5 percent in 1892 and 1896, respectively, against 53.8 and 76.2 percent for whites. Similarly, as reported by the U.S. Commission on Civil Rights (1965), black registration decreased from almost 70 percent in 1867 to less than 6 percent in 1892. The state of Mississippi has been one of the first U.S. states to enact disfranchisement schemes. These schemes have often been considered responsible for the decline in turnout and the persistence of the Democrats' hegemony in the South. However, in Mississippi and the rest of the South, turnout started its decrease well before the 1890s. This fall was associated with a sharp decline in black participation which originated in the 1870s and was mainly attributable to the use of fraud, intimidation, and violence. "In the election of 1875 local Democratic clubs announced that no Negro who voted for a Republican could hope for any form of employment. Checkers were stationed at the polls, and groups of armed men intercepted Negroes on their way to register. Negro Political leaders were threatened that continued activity would results in deaths. As a result of these tactics, Negro voting diminished throughout the state and Democrats returned to power" (U.S. Commission of Civil Rights, 1965). This downward trend may suggest that the enactment of disfranchisement schemes in the South was ineffective because they simply consolidated a state of affairs which was already in place before their introduction.

In this section we use previously-unexploited data on voter registration by race for the counties of Mississippi - collected from the Interrogatory Answers and only available for the years 1896 and 1899 - to evaluate the determinants of voter registration. It is worth stressing again that this novel source of data contains unique historical information on raciallydisaggregated patterns, even though this information is limited by its availability for only two points in time, both falling after the enactment of the 1890 constitution.

\footnotetext{
${ }^{7}$ In contexts other than the U.S., Baland and Robinson (2008) look at the effect of the introduction of the secret ballot in Chile in 1958 to find that the change in political institutions had implications for voting behaviour, while for a sample of Latin American countries during the twentieth century Aidt and Eterovic (2011) show that the abolition of the literacy test increased redistributive policies.
} 
To assess the potential influence of the de jure innovations that uniformly affected all counties in our sample, we test whether the variation in the proportion of registered blacks responds to proxies for their level of literacy and wealth, which in turn should capture the effectiveness of the literacy test and the poll tax. If the de jure innovations introduced by the 1890 constitution were such to influence electoral outcomes, we should expect the difference in black registration to depend strongly on the variation in these variables. At the same time, we can gauge how registration responds to de facto elements reflecting the racial balance of power. If the variation in black registration is determined by de jure constraints, once we control for them de facto elements should not display any explanatory power.

In more detail, our first set of regressors includes proxies for the de jure constraints introduced by the 1890 constitution, i.e., the literacy test and the poll tax. Even though these requirements were imposed on all residents of the state of Mississippi, their practical relevance should respectively vary with literacy and with the ability to pay, which in turn differ between races and across counties. Thus, we employ the literacy rate for black adult (i.e., above age 21) males as an indicator of the impact of the literacy test. Accordingly, counties associated with larger shares of literate black men should exhibit higher black registration. To proxy for blacks' wealth, and therefore for the impact of the poll tax, ${ }^{8}$ we use three variables: sharecropping intensity, black immigration, and black infant mortality. Sharecropping intensity should be associated with tighter cash flow availability and consequently with a larger impact of the poll tax (see Kousser, 1974), so that we should expect a negative association between sharecropper intensity and registration. Consistent with migration theory, ${ }^{9}$ blacks should leave counties where their wage is lower. ${ }^{10}$ Thus, we should observe a positive correlation between immigration and registration. Infant mortality is influenced by diseases and malnutrition and is therefore closely associated with low income levels, ${ }^{11}$ so that we should expect a negative correlation with registration. To sum up, we interpret black literacy, sharecropping intensity, black immigration, and black infant mortality as variables capturing the effectiveness of the de jure determinants of voter registration.

\footnotetext{
${ }^{8}$ In Mississippi the tax was cumulative, with a maximum total charge of four dollars. For the bottom three quarters of the southern population 1890 per capita income (including non-cash components) is estimated by Kousser (1974) at about 64 dollars.

${ }^{9}$ See Harris and Todaro (1970).

${ }^{10}$ See Irwin and O’Brien (2001) for migration patterns in the Mississippi Yazoo Delta in 1880-1910.

${ }^{11}$ See the Report on Vital Statistics in the 1880 and 1890 census. See also Haines (2011) on the use of infant mortality as a proxy for economic and social conditions.
} 
Our main de facto determinant of voter registration is a dummy variable which takes value one for counties where blacks represent the majority (i.e., more than 50 percent) among eligible $^{12}$ voters, and therefore captures the potentially pivotal role of blacks. Even though counties are not electoral jurisdictions, this dummy variable should proxy for factors reflecting racial conflict, consistent with the literature suggesting that the opposition to black registration was tougher in counties where blacks represented the majority. We employ this variable together with a measure of black adult male population which should capture other demographic and socio-economic effects, in such a way that the majority-black dummy should indeed exclusively reflect its influence on race-related political conflict. We also rely on a direct measure of racial violence represented by the intensity of black lynching (as in Jones, Troesken and Walsh, 2013). Furthermore, we control for land inequality in order to capture the relative influence of the landowning white elite, whose presence may represent another de facto impediment to black political participation (as suggested by Acemoglu and Robinson, 2008a). ${ }^{13}$

In Table 1 we report descriptive statistics for our two-year panel comprising 75 counties of Mississippi at the turn of the century. While for our controls, mostly based on census data, we actually have no time variability, using information both about 1896 and 1899 allows us to fully exploit the variability in the dependent variable. Data sources are reported in Table A1 in the Appendix.

The table shows that our main dependent variable, black registration, ${ }^{14}$ is less than one fifth of white registration: ${ }^{15}$ the average share of black adult males who register is 15.4 percent against 78.1 percent for whites. ${ }^{16}$

Next we report statistics for our proxies for de jure power. Black literacy, i.e., the share of literate black adult males, is much lower than that for whites (47.6 percent against 92.2 percent). ${ }^{17}$ The index of sharecropping intensity ${ }^{18}$ is on average 29.1 percent, with the highest

\footnotetext{
${ }^{12}$ The latter consists of males over 21 years of age, with a few disqualifications, for instance in the case of felony. ${ }^{13}$ See Vollrath (2013) for a detailed discussion on the link between our measure of land inequality, based on the distribution of farms by size, and wealth distribution in 1890 .

${ }^{14}$ Black registration is equal to the ratio of the number of registered blacks in 1896 and 1899 to black male population of age 21 and above in 1900 (the closest available year as in Kousser, 1974). We proceed in a similar fashion for white registration.

${ }^{15}$ In 1896 the total number of registered blacks and whites is 16,234 and 108,998, respectively. These figures are consistent with totals provided by the Biennial Report of the State Superintendent of Public Education to the Legislature of Mississippi (1897). The correlation between black registration in 1896 and 1899 is 93 percent.

${ }^{16}$ The maximal white registration is above 100 percent because of frauds, which at the time were common in the South. For example Kousser (1974, p. 49) reports that white registration in Louisiana in 1897 is 103.2 percent.

${ }^{17}$ We use data on the share of literates in 1900 because figures for the adult population are available only for this year.

${ }^{18}$ The index of sharecropping intensity is calculated as the ratio of farm population under a sharecropping scheme to total farm population. The index is equal to one if all farm population is under a sharecropping scheme.
} 
share in Issaquena county (over 80 percent). The infant mortality rate for blacks in 1880 (the closest available year), measured as the rate of death in black population under one year of age, is on average 4.5 percent, with a maximum at 11.3 percent in Clay and a minimum at 1 percent in Jasper. We calculate a proxy for black immigration which is equal to the difference between black population in 1890 and black population in 1880, the latter augmented by the difference between birth and death rates in 1880 and 1890. From census data ${ }^{19}$ we know that the annual rate of birth among blacks is 3.1 percent and the annual rate of death is 1.5 percent. ${ }^{20}$ Using this measure we estimate an average immigration rate in $1880-1890$ of one percent, ${ }^{21}$ with a peak of 44.3 percent in Quitman. ${ }^{22}$

Finally we report statistics for de facto controls, starting with the number of black adult males in 1900, followed by the corresponding figure for whites: the former is larger on average and exhibits a much larger variation. ${ }^{23}$ Blacks represent a political majority in 45 percent of the sample, that is in 34 counties. Lynchings of blacks in the 1882-1896 period are on average 2 per county, with a maximum of 11 for both Hinds and Lowndes. ${ }^{24}$ Land inequality, ${ }^{25}$ urban population (both as of 1890), and total population in 1900 also vary significantly across counties.

Overall, the descriptive statistics in Table 1 provide some preliminary evidence about the importance of the potential political influence of blacks as a disfranchisement factor. Take for instance the case of Smith county, which shows in 1896 the highest rate of black registration at 53.1. The corresponding share of black adult males is only 16.8 percent, well below the majority and therefore unable to represent a credible threat to white Democrats, which suggests that tough opposition was not required in order to keep a white hegemony, as explained by Wharton (1947). At the same time black literacy is 47 percent, i.e., almost exactly equal to the mean,

\footnotetext{
${ }^{19}$ The birth and death rates for 1880-1890 are provided by the Report on Vital Statistics of the 1890 census.

${ }^{20}$ The number of blacks in Mississippi in the 1890 census is 742,559. However, if we augment the 1880 number of blacks by taking into account birth and death rates, we obtain an estimated number of blacks in 1890 of 747,835. We impute this difference to out-of-state migration.

${ }^{21}$ If we take the difference between the share of blacks (including slaves and free coloured) in 1860 and the share of blacks in 1890 for the 60 counties that exist in 1860 we find that the increase in the share of blacks is 0.7 percent, which is larger than what previously reported in the text because of the creation of new counties from lands of preexisting counties in the 1860s and the 1870s. We introduce our estimates of immigration because of the lack of comparability between the counties in place in 1860 and 1890 .

${ }^{22}$ In Quitman the bottomlands behind the riverfront were developed for cotton cultivation only in the late nineteenth century, causing a continuous increase in the population. Sizeable relocations of the black population were similarly present across other counties.

${ }^{23}$ As a term of comparison, in 1890 la share of blacks over total population is 51.8 percent.

${ }^{24}$ Data are from Project HAL: Historical American Lynching. We count all episodes of lynchings of blacks reported for the 1882-1896 period.

${ }^{25}$ To compute land inequality we use the Generalized Entropy Index ( $\left.a=-1\right)$.
} 
while black infant mortality and sharecropping intensity are both below the mean, at 3.9 and 15 percent respectively. At the other extreme, in Tunica black registration is only 3.9 percent, against a share of black adult males at 88 percent (despite the fact that black literacy is above the mean at 53 percent and black infant mortality is below at 3.9).

Table 1: Descriptive Statistics, Mississippi

\begin{tabular}{llllll}
\hline Variable (reference years) & Obs. & Mean & Std. Dev. & Min & Max \\
\hline & & & & & \\
Black Registration (1896-1899) & 150 & .154 & .138 & .007 & .662 \\
White Registration (1896-1899) & 150 & .781 & .188 & .344 & 1.376 \\
Black Literacy (1900) & 150 & .476 & .071 & .340 & .792 \\
White Literacy (1900) & 150 & .922 & .042 & .798 & .992 \\
Sharecropping Intensity (1890) & 150 & .291 & .154 & .014 & .813 \\
Black Infant Mortality (1880) & 150 & .045 & .017 & .010 & .113 \\
Black Immigration (1880-1890) & 148 & .011 & .124 & -.262 & .443 \\
Black Adult Male Population (1900) & 150 & $2,637.627$ & $2,250.895$ & 213 & 12,041 \\
White Adult Male Population (1900) & 150 & $1,944.2$ & 794.739 & 208 & 4,665 \\
Majority-Black Dummy (1900) & 150 & .453 & .499 & 0 & 1 \\
Lynching (1882-1896) & 150 & 2.027 & 2.596 & 0 & 11 \\
Land Inequality (1890) & 150 & 1.328 & .574 & .611 & 4.738 \\
Urban Population (1890) & 150 & 932.88 & $2,557.956$ & 0 & 13,373 \\
Population (1900) & 150 & $20,683.6$ & $9,463.552$ & 5,435 & 52,577 \\
\hline
\end{tabular}

In Table 2 we regress black registration on our de jure and de facto controls. In Model 1 we include all de jure controls (i.e., black literacy for the effect of the literacy test and sharecropping intensity, black immigration, and black infant mortality for the effect of the poll tax), plus two of the candidate de facto controls (i.e., lynching and land inequality). Black literacy exhibits a positive coefficient, as expected, but it is not significant. The three proxies for black wealth and the effectiveness of the poll tax are all significant. The negative coefficients for sharecropping intensity and infant mortality confirm the hypothesis that counties where cash availability is lower and diseases and malnutrition are more pervasive should exhibit lower black registration. The negative coefficient for black immigration is instead against the hypothesis that blacks should be moving where wages are higher: this suggests that the influx of blacks, which carries implications also for the racial composition of the local population, may reflect other factors related to the de facto racial balance of power. Turning to de facto controls, lynching and land inequality are both significant and with the expected sign, confirming that physical violence and the presence of a wealthy white elite contribute to reduce 
black enfranchisement. Controls for the total size of the population, urban population and a dummy for the year 1899 are also inserted.

When in Model 2 we add the number of black adult males to the initial specification, previous results are largely confirmed, even though black literacy now shows a highly significant coefficient. Since the racial composition of the population is now accounted for, black immigration turns to the expected positive influence, although it is no longer significant. Besides, the newly-added variable significantly decreases black registration, consistent with the view that attributes a large explanatory power to racial factors. ${ }^{26}$ Race might indeed have been used as a signalling device. Given that the easiest way to ensure a Democratic victory in the election was to exclude potential voters for Republicans, and given that blacks were likely to vote Republican, race was the simplest characteristic which revealed voting preferences.

However, one could convincingly argue that black adult male population reflects not only political factors but rather a variety of demographic and socio-economic ones. Therefore, in Model 3 we also enter our focal variable, i.e., the dummy for a black political majority, which is meant to capture the potentially pivotal role of blacks in the electoral process. While black adult male population maintains its significance, the majority-black dummy exerts a highly significant negative effect on registration which can be attributed to the political channel of influence. Out of the remaining controls, in this specification only black literacy and land inequality remain significant. Even the intensity of violence as captured by lynching is no longer significant after racial factors are accounted for.

Table 2: Determinants of Voter Registration by Race, Mississippi, 1896-1899

\begin{tabular}{|c|c|c|c|c|}
\hline \multicolumn{5}{|c|}{ Dependent Variable: Registration by Race } \\
\hline & Model 1 & Model 2 & Model 3 & Model 4 \\
\hline Estimation Method: OLS & Blk Registr. & Blk Registr. & Blk Registr. & Blk Registr. \\
\hline
\end{tabular}

\footnotetext{
${ }^{26}$ We check for non-linearities by entering also the squared term of black adult male population, which however is not significant. We also replace black adult male population with slave population in 1860. The correlation between the two variables is 0.60 since the former excludes women and non-adult men (the correlation between the black share in 1900 and the slave share in 1860 is 0.95). Using the slave share reduces the number of counties to 60 . Nevertheless results are similar. For brevity we do not report regressions for these checks.
} 


\begin{tabular}{|c|c|c|c|c|}
\hline Black Literacy & $\begin{array}{l}0.167 \\
(0.135)\end{array}$ & $\begin{array}{l}0.384 * * * \\
(0.139)\end{array}$ & $\begin{array}{l}0.265^{* *} \\
(0.121)\end{array}$ & $\begin{array}{l}0.238^{*} \\
(0.129)\end{array}$ \\
\hline Sharecropping Intensity & $\begin{array}{l}-0.283^{* * *} \\
(0.065)\end{array}$ & $\begin{array}{l}-0.189 * * * \\
(0.064)\end{array}$ & $\begin{array}{l}-0.063 \\
(0.065)\end{array}$ & $\begin{array}{l}-0.173^{*} \\
(0.099)\end{array}$ \\
\hline Black Immigration & $\begin{array}{l}-0.247^{* * *} \\
(0.065)\end{array}$ & $\begin{array}{l}0.0003 \\
(0.087)\end{array}$ & $\begin{array}{l}0.035 \\
(0.076)\end{array}$ & $\begin{array}{l}-0.033 \\
(0.097)\end{array}$ \\
\hline Black Infant Mortality & $\begin{array}{l}-1.031^{* *} \\
(0.480)\end{array}$ & $\begin{array}{l}-0.810^{*} \\
(0.460)\end{array}$ & $\begin{array}{l}-0.433 \\
(0.455)\end{array}$ & $\begin{array}{l}-0.552 \\
(0.444)\end{array}$ \\
\hline Lynching (log) & $\begin{array}{l}-0.033^{* *} \\
(0.013)\end{array}$ & $\begin{array}{l}-0.023^{*} \\
(0.014)\end{array}$ & $\begin{array}{l}-0.014 \\
(0.015)\end{array}$ & $\begin{array}{l}-0.022 \\
(0.015)\end{array}$ \\
\hline Land Inequality & $\begin{array}{l}-0.084^{* * *} \\
(0.017)\end{array}$ & $\begin{array}{l}-0.074 * * * \\
(0.017)\end{array}$ & $\begin{array}{l}-0.068^{* * *} \\
(0.016)\end{array}$ & $\begin{array}{l}-0.057 * * * \\
(0.021)\end{array}$ \\
\hline Black Adult Male Population (log) & & $\begin{array}{l}-0.448^{* * *} \\
(0.117)\end{array}$ & $\begin{array}{l}-0.340^{* * *} \\
(0.111)\end{array}$ & $\begin{array}{l}-0.420^{* * *} \\
(0.148)\end{array}$ \\
\hline Majority-Black Dummy & & & $\begin{array}{l}-0.092^{* * *} \\
(0.017)\end{array}$ & $\begin{array}{l}-0.099 * * * \\
(0.018)\end{array}$ \\
\hline Constant & $\begin{array}{l}1.567 * * * \\
(0.292)\end{array}$ & $\begin{array}{l}0.608^{*} \\
(0.340)\end{array}$ & $\begin{array}{l}0.495 \\
(0.327)\end{array}$ & $\begin{array}{l}4.179 * * \\
(1.988)\end{array}$ \\
\hline Population (log) & Yes & Yes & Yes & Yes \\
\hline Urban Population (log) & Yes & Yes & Yes & Yes \\
\hline Year $=1899$ & Yes & Yes & Yes & Yes \\
\hline Jackson Dummy & & & & Yes \\
\hline Mississippi River Delta Dummy & & & & Yes \\
\hline Distance in Longitude from Jackson & & & & Yes \\
\hline Distance in Latitude from Jackson & & & & Yes \\
\hline Observations & 148 & 148 & 148 & 148 \\
\hline R-squared & 0.41 & 0.45 & 0.50 & 0.52 \\
\hline
\end{tabular}

Robust standard errors in parentheses. ${ }^{* * *} \mathrm{p}<0.01,{ }^{* *} \mathrm{p}<0.05,{ }^{*} \mathrm{p}<0.1$.

Finally in Model 4, to control for observable confounding variables, we also include a set of geographical variables. Namely, we include a dummy for Jackson, the state capital, because in this county Republicans had a strong organization. We also control for distance from Jackson (both in latitude and longitude). A dummy for counties on the Mississippi River Delta is meant to capture its particular characteristics (agricultural plains with the largest black shares and land inequality). In this extended specification black adult male population and the majority-black dummy are still both significant at the one percent level, and so is land inequality. In particular, the presence of a black political majority decreases black registration by 9.9 percent, an additional one percent of black adult male residents decreases it by 0.42 percent, and a standard 
deviation in land inequality decreases it by 7.6 percent. Black literacy and sharecropping intensity are now significant at the 10 percent level.

Overall, the R-squared (between 0.45 and 0.52 in the three models in Table 2 that include black adult population) implies that these models can explain a large portion of the variation in black registration.

In Table 3 we re-estimate the full specification of Model 4, Table 2 over different subsamples. To dig into the role of the presence of a black political majority, in Models 1 and 2 we split our sample between counties with and without one. Black adult male population is only significant for the former sub-sample (Model 1) and contributes to a substantial increase in the explanatory power of the model, as captured by the R-squared. The significance level of the de jure controls and lynching is also larger within this sub-sample if compared to the full one. On the other hand, in the majority-white sub-sample (Model 2) only land inequality is significant and the R-squared is modest. These results confirm that the de jure restrictions introduced by the 1990 constitution were more effective in counties where blacks' political threat was larger. The fact that de jure factors acquire an increased importance when a black political majority is present can be explained by a stricter enforcement of the rule in the corresponding counties. This was made possible through the use of the discretionary authority of white officials, which was directed against blacks as amply documented.

In Models 3 and 4 we divide our sample between 1896 and 1899: due to the reduced sample size, most regressors lose significance, but the dummy for a black political majority remains significant at the one percent level. Black adult male population is also still significant, while de jure controls are not.

In the last column of Table 3 (Model 5) we go back to the full sample to estimate a model for white registration, where the presence of a black political majority is the only significant control. Its positive relationship with the dependent variable suggests a more active mobilization of whites when their hegemony was under threat. The lack of significance of the other controls can be explained by the large proportion of registered whites, over 78 percent on average and therefore in line with turnout in a full democracy. It is therefore plausible that restrictions introduced with the 1890 constitutions had no effect on the white electorate, as confirmed by the insignificance of the coefficient of white literacy. 
Table 3: Determinants of Voter Registration by Race, Mississippi, 1896-1899 - Extensions

\begin{tabular}{|c|c|c|c|c|c|}
\hline \multicolumn{6}{|c|}{ Dependent Variable: Registration by Race } \\
\hline & Model 1 & Model 2 & Model 3 & Model 4 & Model 5 \\
\hline Estimation Method: OLS & Blk Registr. & Blk Registr. & Blk & Blk Registr. & Wht Registr. \\
\hline Black Literacy & $\begin{array}{l}0.244^{* *} \\
(0.110)\end{array}$ & $\begin{array}{l}-0.0677 \\
(0.246)\end{array}$ & $\begin{array}{l}0.176 \\
(0.166)\end{array}$ & $\begin{array}{l}0.299 \\
(0.215)\end{array}$ & \\
\hline Sharecropping Intensity & $\begin{array}{l}0.053 \\
(0.051)\end{array}$ & $\begin{array}{l}-0.500 \\
(0.305)\end{array}$ & $\begin{array}{l}-0.197 \\
(0.139)\end{array}$ & $\begin{array}{l}-0.149 \\
(0.155)\end{array}$ & \\
\hline Black Immigration & $\begin{array}{l}0.169 * * * \\
(0.054)\end{array}$ & $\begin{array}{l}0.083 \\
(0.385)\end{array}$ & $\begin{array}{l}-0.057 \\
(0.129)\end{array}$ & $\begin{array}{l}-0.009 \\
(0.157)\end{array}$ & \\
\hline Black Infant Mortality & $\begin{array}{l}-0.722 * * \\
(0.278)\end{array}$ & $\begin{array}{l}-0.743 \\
(1.263)\end{array}$ & $\begin{array}{l}-0.298 \\
(0.568)\end{array}$ & $\begin{array}{l}-0.807 \\
(0.754)\end{array}$ & \\
\hline Lynching (log) & $\begin{array}{l}-0.021 * \\
(0.011)\end{array}$ & $\begin{array}{l}-0.019 \\
(0.031)\end{array}$ & $\begin{array}{l}-0.029 \\
(0.022)\end{array}$ & $\begin{array}{l}-0.016 \\
(0.023)\end{array}$ & $\begin{array}{l}0.022 \\
(0.022)\end{array}$ \\
\hline Land Inequality & $\begin{array}{l}-0.025 \\
(0.022)\end{array}$ & $\begin{array}{l}-0.060^{* *} \\
(0.028)\end{array}$ & $\begin{array}{l}-0.054^{* *} \\
(0.025)\end{array}$ & $\begin{array}{l}-0.059 \\
(0.037)\end{array}$ & $\begin{array}{l}-0.039 \\
(0.027)\end{array}$ \\
\hline Black Adult Male Pop. (log) & $\begin{array}{l}-0.579 * * * \\
(0.077)\end{array}$ & $\begin{array}{l}0.0416 \\
(0.426)\end{array}$ & $\begin{array}{l}-0.374 * \\
(0.196)\end{array}$ & $\begin{array}{l}-0.466^{*} \\
(0.242)\end{array}$ & \\
\hline Majority-Black Dummy & & & $\begin{array}{l}-0.082^{* * *} \\
(0.055)\end{array}$ & $\begin{array}{l}-0.115^{* * *} \\
(0.029)\end{array}$ & $\begin{array}{l}0.120^{* *} \\
(0.062)\end{array}$ \\
\hline White Literacy & & & & & $\begin{array}{l}0.505 \\
(0.518)\end{array}$ \\
\hline White Adult Population (log) & & & & & $\begin{array}{l}0.093 \\
(0.060)\end{array}$ \\
\hline Constant & $\begin{array}{l}-0.200 \\
(1.020)\end{array}$ & $\begin{array}{l}9.572^{* *} \\
(4.009)\end{array}$ & $\begin{array}{l}4.902 * \\
(2.717)\end{array}$ & $\begin{array}{l}3.476 \\
(3.171)\end{array}$ & $\begin{array}{l}1.862 \\
(2.302)\end{array}$ \\
\hline Population (log) & Yes & Yes & Yes & Yes & Yes \\
\hline Urban Population (log) & Yes & Yes & Yes & Yes & Yes \\
\hline Year = 1899 & Yes & Yes & & & Yes \\
\hline Jackson Dummy & Yes & Yes & Yes & Yes & Yes \\
\hline Mississippi River Delta D. & Yes & Yes & Yes & Yes & Yes \\
\hline Dist. Longitude from Jackson & Yes & Yes & Yes & Yes & Yes \\
\hline $\begin{array}{l}\text { Dist. Latitude from Jackson } \\
\text { Observations }\end{array}$ & $\begin{array}{l}\text { Yes } \\
68\end{array}$ & $\begin{array}{l}\text { Yes } \\
80\end{array}$ & $\begin{array}{l}\text { Yes } \\
74\end{array}$ & $\begin{array}{l}\text { Yes } \\
74\end{array}$ & $\begin{array}{l}\text { Yes } \\
150\end{array}$ \\
\hline R-squared & 0.72 & 0.29 & 0.52 & 0.53 & 0.28 \\
\hline Sample & $\begin{array}{l}\text { If } \\
\text { Majority } \\
\text { Black }\end{array}$ & $\begin{array}{l}\text { If } \\
\text { Majority } \\
\text { White }\end{array}$ & $\begin{array}{l}\text { If } \\
\text { Year }=1896\end{array}$ & $\begin{array}{l}\text { If } \\
\text { Year=1899 }\end{array}$ & Full sample \\
\hline
\end{tabular}

Robust standard errors in parentheses. ${ }^{* * *} \mathrm{p}<0.01$, ${ }^{* *} \mathrm{p}<0.05,{ }^{*} \mathrm{p}<0.1$. 
Overall, our results suggest a marginal and non-robust effect of poll taxes and literacy tests on black registration. On the other hand there is evidence of a strong effect of race, as captured by the presence of a black political majority. It is indeed only in counties where eligible blacks are more than 50 percent that de jure constraints appear to have been enforced effectively.

Even though county-level data on voter registration by race are only available for the postconstitution period, with consequent limitations in terms of identification, our findings show that they do provide key information on the racial distribution of political participation and suggestive evidence of the effect of legal requirements on blacks. This effect tends to be underestimated using data on aggregate turnout since the average effect is likely to be affected by the marginal impact of legal requirements on whites. For example, following the application of the disfranchisement schemes there may have been a sort of re-shuffling in voting patterns between whites and blacks (with a decline in black voters and an increase in white), mainly in black counties, due to the increasing animosity toward blacks. This levelling effect can produce either an insignificant or positive effect of disfranchisement on turnout.

To conclude, while the Interrogatory Answers provide precious information on raciallydisaggregated political outcomes for the counties of Mississippi, they suffer of two inter-related shortcomings. First of all, they exclusively cover counties of a single state, where constitutional innovations were uniformly applied. Second, they only offer observations for the period after the implementation of the constitutional reform. To address these shortcomings, in this section we turn to a complementary difference-in-differences approach.

\section{A Difference-in-Differences Approach}

In this section we turn to data on voter turnout (defined as number of voters over eligible population) which are universally available at the county level for several states and are consistently measured through time before and after the 1890 Mississippi new constitution. These data, which we take from Clubb, Flanigan and Zingale (2006), in turn present the disadvantage of not reporting turnout by race. However, aggregate turnout over the time period of interest is highly correlated with black registration. Table 4 reports the pairwise correlations between electoral outcomes for the 1896 presidential election in Mississippi. Data on black and white registration are from the Interrogatory Answers while overall turnout and Democratic and Republican party shares are from by Clubb, Flanigan and Zingale (2006). The correlation between black registration and total turnout is above 0.75. Moreover, the correlation between black registration and the other available figures is much lower, suggesting that it is the variation 
in black registration that matters most for the variation in turnout. Therefore, in order to identify a causal channel which is missing in the previous section, we can exploit turnout data to compare the counties in Mississippi, the treated group, with an appropriately selected out-ofstate control group which was not exposed to de jure restrictions.

Table 4: Correlations between Registration and Turnout, Mississippi, 1896

Blk Registr. Wht Registr. Turnout Democratic Vote Sh Republican Vote Sh

$\begin{array}{llllll}\text { Black Registration } & 1.0000 & & & & \\ \text { White Registration } & 0.0621 & 1.0000 & & & \\ \text { Turnout } & 0.7528 & 0.1685 & 1.0000 & \\ \text { Democratic Vote Share } & -0.3384 & 0.1690 & -0.2613 & 1.0000 & 1.0000 \\ \text { Republican Vote Share } & 0.0139 & -0.2471 & -0.2579 & -0.4431 & 1\end{array}$

In order to select an appropriate control group, in Table 5 we report the timeline of the introduction of poll taxes and literacy tests in all southern states. Three states (Arkansas, Florida, and Tennessee) only had a poll tax, while the remaining eight states including Mississippi had both a poll tax and a literacy test. Out the latter eight, only four states - North Carolina, Alabama, Texas, and Virginia - introduced legal voting requirements after Mississippi did, between 1900 and 1902. However, Virginia had had a poll tax, which was later repealed, even before 1881. For these reasons, we focus on North Carolina, Alabama, and Texas as proper terms of comparison with Mississippi.

Table 5: Poll Tax and Literacy Test, Years of Introduction

\begin{tabular}{lcc}
\hline State & Poll Tax & Literacy Test \\
\hline & & \\
Alabama & 1901 & 1901 \\
Arkansas & 1892 & - \\
Florida & 1889 & - \\
Georgia & 1877 & 1908 \\
Louisiana & 1898 & 1898 \\
Mississippi & 1890 & 1890 \\
North Carolina & 1900 & 1900 \\
South Carolina & 1895 & 1895 \\
Tennessee & 1890 & - \\
Texas & 1902 & 1902 \\
Virginia* & 1902 & 1902 \\
\hline
\end{tabular}

Source: Kousser (1974, Table 9.1). * Virginia had a poll tax also before 1881.

Table 6 reports average turnout for Mississippi, North Carolina, Alabama, and Texas over the 1876-1900 period, both for presidential and congressional elections. Turnout data for the 
two types of elections are kept separate since, generally speaking, they are always consistently higher for the former. Over this time period, for both types of elections, turnout in Mississippi is on average by far the lowest, while Alabama comes next. For presidential elections, Mississippi already shows a declining trend (from 75.6 in 1876 to 45.9 percent in 1888) before 1890. After that, turnout for presidential elections fluctuates around 20 percent. Instead, turnout for congressional elections is always quite low. Over the same period, turnout for presidential elections in Alabama declines initially, from 72 in 1876 to 58.1 percent four years later, to remain relatively stable around 50 percent with the exception of a peak in 1892. On the other hand, for North Carolina and Texas turnout tends to be larger, with a tendency to increase over time both for presidential and congressional elections.

Table 6: Voter Turnout in Four Southern States, 1876-1900

\begin{tabular}{lcccc}
\hline Year & Mississippi & Alabama & N. Carolina & Texas \\
\hline Presidential elections & & & & \\
1876 & 0.756 & 0.720 & 0.863 & 0.434 \\
1880 & 0.502 & 0.581 & 0.806 & 0.611 \\
1884 & 0.498 & 0.534 & 0.834 & 0.724 \\
1888 & 0.459 & 0.568 & 0.849 & 0.706 \\
1892 & 0.203 & 0.696 & 0.794 & 0.738 \\
1896 & 0.248 & 0.539 & 0.858 & 0.782 \\
1900 & 0.191 & 0.424 & 0.717 & 0.683 \\
Average & 0.408 & 0.580 & 0.817 & 0.668 \\
\hline & & & & \\
Congressional elections & & & & \\
1878 & 0.220 & 0.343 & 0.431 & 0.634 \\
1882 & 0.355 & 0.455 & 0.705 & 0.601 \\
1886 & 0.197 & 0.284 & 0.640 & 0.634 \\
1890 & - & 0.375 & 0.731 & 0.663 \\
1894 & 0.148 & 0.4 & 0.761 & 0.724 \\
1898 & 0.09 & 0.261 & 0.836 & 0.660 \\
Average & 0.202 & 0.353 & 0.684 & 0.653 \\
& & & & \\
\hline Average (Pres. and & 0.287 & 0.465 & 0.756 & 0.669 \\
\hline
\end{tabular}

Given the relatively similar pattern of turnout for Alabama and Mississippi, we evaluate the effect of the 1890 constitutional restrictions in Mississippi on voting turnout using Alabama (that introduced restrictions only in 1901) as a control. We focus on the $1882-1900$ period. ${ }^{27}$ In more detail, the model we estimate to test the possible causal effect of the 1890 constitutional reform can be written as:

\footnotetext{
${ }^{27}$ We start from 1882 since lynching data are available since then.
} 


$$
\text { Turnout }_{i, t}=\alpha_{j}+\lambda_{t}+\alpha_{j} t+\beta_{1} \text { Post }_{i, t}+\beta_{2} \operatorname{MajBl}_{i, t}+\beta_{3} \text { Post }_{i, t} * \operatorname{MajBl}_{i, t}+\beta_{4} X_{i, t}+\mu_{i, t}
$$

where the sample includes counties in Mississippi (the treated group) and Alabama (the control group). The dependent variable is voter turnout over the 1882-1900 period, including both presidential and congressional elections. Parameters $\alpha_{j}$ and $\lambda_{t}$ capture state and time fixed effects and $\alpha_{j}, t$ are separate linear time trends for each state which should control for differences in time trend across state. Therefore the model controls for different time trend across the two groups $\left(\alpha_{j}, t\right)$ and for transitory shocks in turnout $\left(\lambda_{t}\right)$. The latter are used to control for possible violations of the common trend hypothesis. Post $t_{i, t}$ is a dummy variable for Mississippi's counties after 1890 which should capture the effect of the legal requirements introduced in the 1890 Mississippi constitution (the treatment). $M a j B l_{i, t}$ is a dummy variable that takes value one for counties exhibiting a black political majority, i.e., if blacks are more than 50 percent of eligible voters. Consistent with the literature and our previous findings, we interpret it as a proxy of de facto disfranchisement, since opposition to black registration was tougher in majority-black counties. Post ${ }_{i, t}{ }^{*} M a j B l_{i, t}$ is an interaction term that should capture a change in the slope coefficient of the majority-black dummy after 1890 . While the variables Post $_{i, t}$ and $M a j B l_{i, t}$ reflect respectively the separate effect of de jure and de facto disfranchisement, their interaction Post $_{i, t} * M_{a j B l}$, should capture a change in the relationship between a black political majority and turnout after 1890 which can be interpreted as a sort of institutionalization of the de facto disfranchisement of black voters, achieved through the introduction of the legal restrictions. The above equation also includes individual time-varying county characteristics $X_{i, t .}$ Depending on the specification, they consist of combinations of lagged turnout, to control for its persistence; a dummy for presidential elections, to account for their differential trend in turnout if compared with congressional ones; lynching, to measure racial violence; and black adult male population, to gauge the influence of other potential racially-related determinants. ${ }^{28}$ $\varepsilon_{i, t}$ is the error term.

An essential assumption behind the difference-in-differences estimator is the exogeneity of the treatment, i.e., there should be no reasons why states which had lower turnout enacted disfranchisement schemes sooner. The endogeneity of the treatment is always a potential problem and if we take Key's argument seriously then we should expect some possible endogeneity. This endogeneity bias is likely to over-estimate the effect of disfranchisement

\footnotetext{
${ }^{28}$ Data for black adult male population are taken from relevant census years. The dummy for black political majority varies accordingly. Lynchings are counted for the two-year period preceding each election. See Table A1 for data definitions and sources.
} 
schemes. However, the fact that turnout in Alabama is not that different from the one in Mississippi and the fact that also states in which the trend in turnout was increasing enacted those schemes (e. g., Texas and North Carolina) seem to suggest that turnout should not have any effect on the enactment of voting restrictions. The fact that the timing of the introduction of the schemes across states is independent of turnout is also confirmed by additional inspection. Virginia, which first introduced a poll tax in 1876 (and then abolished it in 1881), had in the same year a turnout close to 71 percent. Turnout in Georgia and Tennessee in the election before the introduction of the schemes (1876 and 1888 respectively) was 63.3 and 79.3 percent. Overall the timing of the introduction of the schemes appears to depend more on de facto power, political will, social conditions, and influences of the central government so that it is exogenous with respect to turnout.

Prior to estimation of the above equation, in Table A2 in the Appendix we estimate a placebo regression in order to spot any change in turnout for Mississippi before the introduction of the new constitution (i.e., over the 1882-1890 period), again using Alabama as a control group. We regress turnout over 1882-1890 against a hypothetical policy introduced after 1886 (i.e., we pick the middle of the $1882-1890$ period) in order to estimate potential differences in trend before 1890. The fact that the effect of this fake policy turns insignificant can be interpreted as evidence of a sort of common trend between Mississippi and Alabama for the 1882-1890 period.

Table 7 shows difference-in-differences county-level estimates for the 1882-1900 period. Even though the main purpose of the table is to gauge the joint influence of the majority- black and the post-constitution dummies, it is instructive to report coefficients also for the main controls. Given the pattern described in Table 6, all models include lagged turnout, whose significant effect confirms strong persistence in voting outcomes. In Model 1 there is on average an increase in turnout of 0.45 percent per a one percent increase in turnout in the previous election. The post-constitution dummy which should capture the effect of the reform in Mississippi is not significant. ${ }^{29}$ As expected, the dummy for presidential elections significantly increases turnout by 25 percent, while an increase in lynchings by one percent decreases turnout by 0.035 . In Model 2 we enter a control for black adult males, which is significant at a five percent level. On average a one percent increase in this regressor decreases turnout by 0.016 percent, consistent with the presence of de facto disenfranchisement of blacks, and also makes lynching insignificant. In Model 3 we add the majority-black dummy, which is highly

\footnotetext{
${ }^{29}$ The post-constitution dummy is significant when we do not control for lagged turnout.
} 
significant and implies a 4 percent reduction in turnout. In turn black adult male population is no longer significant. Finally in Model 4 we also enter the interaction between the majorityblack and the post-constitution dummies, in order to control for a differential effect of the former in the post-constitution period. The dummy for a black political majority remains significant (at five percent level) and the interaction is also significant (at ten percent), which confirms the hypothesis that the effect of de facto measures is strengthened once de jure restrictions are introduced.

Table 7: Determinants of Voter Turnout, Mississippi and Alabama, 1882-1900

\begin{tabular}{|c|c|c|c|c|}
\hline Estimation Method: OLS & Model 1 & Model 2 & Model 3 & Model 4 \\
\hline Lagged Turnout & $\begin{array}{l}0.445^{* * *} \\
(0.027)\end{array}$ & $\begin{array}{l}0.440 * * * \\
(0.028)\end{array}$ & $\begin{array}{l}0.418 * * * \\
(0.031)\end{array}$ & $\begin{array}{l}0.416 * * * \\
(0.031)\end{array}$ \\
\hline Post-Constitution Dummy & $\begin{array}{l}0.044 \\
(0.035)\end{array}$ & $\begin{array}{l}0.038 \\
(0.036)\end{array}$ & $\begin{array}{l}0.029 \\
(0.036)\end{array}$ & $\begin{array}{l}0.036 \\
(0.037)\end{array}$ \\
\hline Presidential Election & $\begin{array}{l}0.250 * * * \\
(0.013)\end{array}$ & $\begin{array}{l}0.249 * * * \\
(0.013)\end{array}$ & $\begin{array}{l}0.244^{* * *} \\
(0.013)\end{array}$ & $\begin{array}{l}0.244^{* * *} \\
(0.013)\end{array}$ \\
\hline Lynching (log) & $\begin{array}{l}-0.035^{* * *} \\
(0.013)\end{array}$ & $\begin{array}{l}-0.019 \\
(0.013)\end{array}$ & $\begin{array}{l}-0.013 \\
(0.013)\end{array}$ & $\begin{array}{l}-0.013 \\
(0.013)\end{array}$ \\
\hline Black Adult Male Pop. (log) & & $\begin{array}{l}-0.016^{* *} \\
(0.007)\end{array}$ & $\begin{array}{l}-0.005 \\
(0.005)\end{array}$ & $\begin{array}{l}-0.006 \\
(0.005)\end{array}$ \\
\hline Majority-Black Dummy & & & $\begin{array}{l}-0.040^{* * *} \\
(0.013)\end{array}$ & $\begin{array}{l}-0.035^{* *} \\
(0.014)\end{array}$ \\
\hline Post-Constitution*Majority-Black Dummy & & & & $\begin{array}{l}-0.019 * \\
(0.011)\end{array}$ \\
\hline Constant & $\begin{array}{l}0.307^{* * *} \\
(0.102)\end{array}$ & $\begin{array}{l}0.164 \\
(0.114)\end{array}$ & $\begin{array}{l}0.164 \\
(0.113)\end{array}$ & $\begin{array}{l}0.162 \\
(0.112)\end{array}$ \\
\hline State Fixed Effects & Yes & Yes & Yes & Yes \\
\hline Year Fixed Effects & Yes & Yes & Yes & Yes \\
\hline State Linear Time Trend & Yes & Yes & Yes & Yes \\
\hline Population & Yes & Yes & Yes & Yes \\
\hline Observations & 1,234 & 1,234 & 1,234 & 1,234 \\
\hline R-squared & 0.67 & 0.68 & 0.68 & 0.68 \\
\hline
\end{tabular}

Results in Table 7 therefore suggest that the registration restrictions in Mississippi had no direct effect on turnout. Decrease in turnout is likely to depend on a long-term trend which initiated well before. De facto drivers of disfranchisement, as captured by the pivotal role of racial factors in the local balance of power, may therefore have been the main cause of turnout 
reduction. The effect of race becomes even more binding after 1890, which implies that the main effect of constitutional reforms may have been an institutionalization of de facto disfranchisement.

To test the robustness of the above results against an alternative control group, in Table A3 in the Appendix we re-estimate the same models as in Table 7 adding North Carolina and Texas to Alabama in the control group. Since in North Carolina the poll tax was introduced in 1900, the estimates are now confined to the 1880-1898 period. If we compare the complete specifications (Models 4 of Tables 7 and A3) under the two alternative control groups, we find that lagged turnout, the dummy for a black political majority, and its interaction with the postconstitution dummy are significant in both models, while the post-constitution dummy per se is not. Under the extended control group the interaction displays a larger and more preciselyestimated coefficient. The reason why the dummy for presidential elections in Table A3 is no longer significant can be attributed to the fact that Texas and North Carolina show a much higher turnout in congressional elections (on average above 60 percent) if compared to Mississippi and Alabama (see Table 5). Lynching is now showing a positive coefficient, which may be due to reverse causality. To sum up, using a broader control group we can confirm both the role of racial political conflict as the main driver of disfranchisement, and its reinforced impact after 1890, consistent again with the hypothesis of an institutionalization of de facto disfranchisement.

Difference-in-differences estimates presented in this section are directly comparable with the findings obtained in the previous section using the Mississippi data. Quantitatively, despite the different samples, the decrease in black registration by 9.9 percent for majority-black counties that we found over the Mississippi data (Table 2, Model 4) is consistent with the decrease in turnout by 4 percent emerging from difference-in-differences estimates (Table 7, Model 3). Qualitatively, both approaches point to a marginal and non-robust effect of poll taxes and literacy tests on black political participation. In particular, the formal legal institutions introduced after Reconstruction appear to be associated with a decrease in black political participation, but they did not alter the balance of political power and rather formalized a status quo produced by other factors reflecting the de facto supremacy of the white elites over the descendants of black slaves. The introduction of the de jure restrictions can be justified as an effort to substitute legal for extorted political control and to ensure the maintenance of white supremacy even in the face of economic and social transformation that may have altered de facto power in the future. Although Wharton (1947) concludes his work on the conditions of 
blacks in Mississippi in the 1865-1890 period by asserting that by 1890 a transition from slavery to a caste system had been completed, and despite the fact that Mississippi did represent an extreme situation of extraordinary violence and discrimination, still even in this state the white elites had some reason to worry about the future. Indeed in 1888 the Republicans had almost managed to pass through Congress the Lodge Election Bill, which would have extended federal supervision of registration and voting and made fraud and intimidation more difficult even in Mississippi. Moreover, there was also evidence of progressive erosion of local Democratic power (see Kousser, 1974).

\section{Conclusion}

With the aid of previously-unexploited information on voter registration, we have investigated the effects of the voter registration restrictions introduced in Mississippi with the 1890 state constitution.

Evidence based on racially-disaggregated voter registration data in the years 1896 and 1899 suggests that de facto determinants of disfranchisement prevail over de jure restrictions as an explanation of the observed pattern of black political participation. In particular, black registration is lower in counties where blacks represented a political majority, consistent with the view that the opposition of white elites was stronger when blacks represented a substantial threat. Our results further suggest that reduced black registration in majority-black counties was also achieved through a stricter enforcement of the legal provisions. Difference-in-differences estimates for aggregate voter turnout confirm a causal effect of the presence of a black political majority on disfranchisement. This effect is strengthened after the introduction of the de jure barriers, which therefore served the purpose of institutionalizing a de facto condition of disfranchisement.

Our findings contribute not only to the literature on the socio-political history of the period that witnessed the restoration of white supremacy in the U.S. South between the end of the nineteenth and the beginning of the twentieth century, but also to a broader current research line on the comparative relevance of de jure and de facto sources of power. The main message of the paper is that the de facto power of the southern white elites was at least as important as the voting legislation as a determinant of black political participation. This conclusion helps to understand why, over fifty years after the Voting Rights Act, enough "vestiges of discrimination" remain despite the removal of "first generation barriers" (Voting Rights Act, 1965). Since voting restrictions were not the exclusive driver of black disfranchisement, their 
de jure reversal was not enough to end racial discrimination. At the same time, the continued potential relevance of legal obstacles to political participation is witnessed by the current debate on the future of the Voting Rights $\mathrm{Act}^{30}$ and the disfranchisement threats that still loom over American society. In particular, the growing application of voter identification provisions is hotly debated. While their enactment is motivated with the need to prevent voter fraud and preserve the integrity of the voting process, their opponents are concerned about their potentially disproportionate impact on minorities, i.e., those social groups who are less likely to possess proper identification. The implications of our results are that future research on the effect of voter identification laws should account for the relative importance of de jure vs. de facto restrictions of political participation and for the possibility that the enactment of such laws may once again represent an institutionalization of a de facto condition of disfranchisement reflecting racial and social conflict.

\section{References}

Acemoglu, D. and Robinson, J.A., The Persistence and Change of Institutions in the Americas, Southern Economic Journal 75, 282-299, 2008a.

Acemoglu, D. and Robinson, J.A., Persistence of Power, Elites, and Institutions, American Economic Review 98, 267-293, 2008b.

Acemoglu, D. and Robinson, J.A., Why Did the West Extend the Franchise? Democracy, Inequality, and Growth in Historical Perspective, Quarterly Journal of Economics 115, 11671199, 2000.

Ades, A. and Verdier, T., The Rise and Fall of Elites: A Theory of Economic Development and Social Polarization in Rent Seeking Societies, CEPR Discussion Paper No. 1495, 1996.

Aidt, T.S. and Eterovic, D.S., Political Competition, Electoral Participation and Public Finance in $20^{\text {th }}$ Century Latin America, European Journal of Political Economy 27, 181-200, 2011.

\footnotetext{
${ }^{30}$ Despite the fact that in 2009 Congress voted to renew its validity until 2031, a 2013 Supreme Court decision struck down a key provision (Section 4), which involved a nearly-automatic obligation to obtain federal preclearance (Section 5) for any changes in electoral practices for jurisdictions that in the past used poll taxes and literacy tests.
} 
Alt, J.E., The Impact of the Voting Rights Act on Black and White Voter Registration in the South, in Davidson, C. and Grofman, B. (eds.), Quiet Revolution in the South: The Impact of the Voting Rights Act, 1965-1990, Princeton University Press, 1994.

Baland, J.M. and Robinson, J.A., Land and Power: Theory and Evidence from Chile, American Economic Review 98, 1737-1765, 2008.

Bertocchi, G. and Dimico, A., Slavery, Education, and Inequality, European Economic Review 70, 197-209, 2014.

Bertocchi, G. and Dimico, A., The Racial Gap in Education and the Legacy of Slavery, Journal of Comparative Economics 40, 581-595, 2012.

Bertocchi, G. and Dimico, A., Race v. Suffrage: The Determinants of Development in Mississippi, CEPR Discussion Paper No. 8589, 2011.

Boettke, P.J., Coyne, C.J. and Leeson, P.T., Institutional Stickiness and the New Development Economics, American Journal of Economics and Sociology 67, 331-358, 2008.

Bond, H.M., Negro Education in Alabama: A Study of Cotton and Steel, Associated Publishers, 1939.

Bond, H.M., The Education of the Negro in the American Social Order, Prentice Hall, Inc., 1934.

Bourguignon, F. and Verdier, T., Oligarchy, Democracy, Inequality and Growth, Journal of Development Economics 62, 285-314, 2000.

Carden, A. and Coyne, C.J., The Political Economy of the Reconstruction Era's Race Riots, Public Choice 157, 57-71, 2013.

Cascio, E.U. and Washington, E., Valuing the Vote: The Redistribution of Voting Rights and State Funds Following the Voting Rights Act of 1965, Quarterly Journal of Economics 129, 379-433, 2014.

Chay, K. and Munshi, K., Black Mobilization After Emancipation: Evidence from Reconstruction and the Great Migration, mimeo, Brown University, 2011.

Clubb, J.M., Flanigan, W.H. and Zingale, N.H., Electoral Data for Counties in the United States: Presidential and Congressional Races, 1840-1972, Inter-university Consortium for Political and Social Research, 2006.

Darmofal, D., The Political Geography of Macro Level Turnout in American Political Development, Political Geography 25, 123-15, 2006.

Filer, J.E., Kenny, L.W. and Morton, R.B., Voting Laws, Educational Policies, and Minority Turnout, Journal of Law and Economics 34, 371-393, 1991. 
Galor, O., Moav, O. and Vollrath, D., Inequality in Landownership, the Emergence of Human Capital Promoting Institutions, and the Great Divergence, Review of Economic Studies 76, 143179, 2009.

Haines, M.R., Inequality and Infant and Childhood Mortality in the United States in the Twentieth Century, Explorations in Economic History 48, 418-428, 2011.

Harris, J.R. and Todaro, M.P., Migration, Unemployment and Development: A Two-Sector Analysis, American Economic Review 60, 126-142, 1970.

Irwin, J.R. and O’Brien, A.P., Economic Progress in the Postbellum South? African American Incomes in the Mississippi Delta, 1880-1910, Explorations in Economic History 38, 166-180, 2001.

Jones, D.B., Troesken, W. and Walsh, R., A Poll Tax by Any Other Name: The Political Economy of Disenfranchisement in the Post-Reconstruction South, mimeo, University of Pittsburgh, 2013.

Key, V.O., Southern Politics in State and Nation, AA Knopf, 1949.

Kousser, J.M., The Shaping of Southern Politics: Suffrage Restriction and the Establishment of the One Party South, 1880-1910, Yale University Press, 1974.

Kousser, J.M., Ecological Regression and the Analysis of Past Politics, The Journal of Interdisciplinary History 4, 237-262, 1973.

Lizzeri, A and Persico, N., Why Did the Elites Extend the Suffrage? Democracy and the Scope of Government, with an Application to Britain's Age of Reform, Quarterly Journal of Economics 119, 707-765, 2004.

Llavador H. and Oxoby, R.J., Partisan Competition, Growth, and the Franchise, Quarterly Journal of Economics 120, 1155-1189, 2005.

Margo, R.A, Race Differences in Public School Expenditures: Disfranchisement and School Finance in Louisiana, 1890-1910, Social Science History 6, 9-23, 1982.

Mississippi State Department of Education, Biennial Report of the State Superintendent of Public Education to the Legislature of Mississippi, 1897.

Naidu, S., Suffrage, Schooling, and Sorting in the Post Bellum U.S. South, NBER Working Paper No. 18129, 2012.

Nunn, N., Slavery, Inequality, and Economic Development in the Americas: An Examination of the Engerman Sokoloff Hypothesis, in Helpman, E. (ed.), Institutions and Economic Performance, Harvard University Press, 2008.

Ogden, F.D., The Poll Tax in the South, University of Alabama Press, 1958. 
Redding, K. and James, D.R., Estimating Levels and Modeling Determinants of Black and White Voter Turnout in the South, 1880 to 1912, Historical Methods 34, 141-158, 2001.

United States v. Mississippi, Interrogatory Answers, Archives and Special Collections, J.D.

Williams Library, The University of Mississippi, 1965.

U.S. Commission on Civil Rights, Voting in Mississippi, 1965.

Voting Rights Act, Public Law 89-110, Eighty-ninth Congress of the United States of America, 1965.

Vollrath, D., Inequality and School Funding in the Rural United States, 1890, Explorations in Economic History 50, 267-284, 2013.

Wharton, V.L., The Negroes in Mississippi 1865-1890, University of North Carolina Press, 1947.

\section{Appendix}

\section{Table A1. Sources of Variables}

\begin{tabular}{|c|c|}
\hline Variable & Source \\
\hline $\begin{array}{l}\text { Black Registration } \\
\text { White Registration }\end{array}$ & $\begin{array}{l}\text { United States v. Mississippi, Interrogatory Answers, Archives and Special } \\
\text { Collections, J.D. Williams Library, The University of Mississippi, } \\
\text { clio.lib.olemiss.edu/cdm/landingpage/collection/usvms_ia. }\end{array}$ \\
\hline $\begin{array}{l}\text { Black Literacy } \\
\text { White Literacy } \\
\text { Sharecropping Intensity } \\
\text { Black Infant Mortality } \\
\text { Black Immigration } \\
\text { Land Inequality } \\
\text { Black Adult Male Population } \\
\text { White Adult Male Population } \\
\text { Majority-Black Dummy } \\
\text { Urban Population } \\
\text { Population }\end{array}$ & $\begin{array}{l}\text { Haines, M.R. and the Inter-university Consortium for Political and Social } \\
\text { Research, Historical, Demographic, Economics, and Social Data: The USA, } \\
\text { 1790-2000, ICPSR02896-v2, Colgate University/Inter-university } \\
\text { Consortium for Political and Social Research, 2004, } \\
\text { www.icpsr.umich.edu/icpsrweb/ICPSR/studies/2896. }\end{array}$ \\
\hline $\begin{array}{l}\text { Presidential Turnout } \\
\text { Congressional Turnout } \\
\text { Democratic Vote Share } \\
\text { Republican Vote Share }\end{array}$ & $\begin{array}{l}\text { Clubb, J.M., Flanigan, W.H. and Zingale, N.H., Electoral Data for } \\
\text { Counties in the United States: Presidential and Congressional Races, } \\
\text { 1840-1972, Inter-university Consortium for Political and Social Research, } \\
\text { 2006, } \\
\text { www.icpsr.umich.edu/icpsrweb/ICPSR/studies/8611. }\end{array}$ \\
\hline Lynching & $\begin{array}{l}\text { Hines, E. and E. Steelwater, Project HAL: Historical American Lynching, } \\
\text { University of North Carolina Wilmington, people.uncw.edu/hinese. }\end{array}$ \\
\hline
\end{tabular}

Table A2: Placebo Regression, Mississippi and Alabama, 1882-1890 


\begin{tabular}{lc} 
Constant & $(0.0310)$ \\
& $0.455^{* * *}$ \\
& $(0.0301)$ \\
State Fixed Effects & Yes \\
Year Fixed Effects & Yes \\
State Linear Time Trend & Yes \\
Observations & 1,318 \\
R-squared & 0.52 \\
\hline Robust standard errors in parentheses. ${ }^{* * *} \mathrm{p}<0.01,{ }^{* *} \mathrm{p}<0.05,{ }^{*} \mathrm{p}<0.1$.
\end{tabular}

Table A3: Determinants of Voter Turnout, Mississippi, Alabama, Texas, and North Carolina, 1882-1898

\begin{tabular}{|c|c|c|c|c|}
\hline Estimation Method: OLS & Model 1 & Model 2 & Model 3 & Model 4 \\
\hline Lagged Turnout & $\begin{array}{l}0.003 * * * \\
(0.0002)\end{array}$ & $\begin{array}{l}0.003^{* * *} \\
(0.0002)\end{array}$ & $\begin{array}{l}0.003^{* * *} \\
(0.0002)\end{array}$ & $\begin{array}{l}0.003^{* * *} \\
(0.0002)\end{array}$ \\
\hline Post-Constitution Dummy & $\begin{array}{l}-0.051 \\
(0.032)\end{array}$ & $\begin{array}{l}-0.050 \\
(0.032)\end{array}$ & $\begin{array}{l}-0.055^{*} \\
(0.031)\end{array}$ & $\begin{array}{l}-0.040 \\
(0.032)\end{array}$ \\
\hline Presidential Election & $\begin{array}{l}-0.014^{* *} \\
(0.007)\end{array}$ & $\begin{array}{l}-0.014^{* *} \\
(0.007)\end{array}$ & $\begin{array}{l}-0.009 \\
(0.007)\end{array}$ & $\begin{array}{l}-0.008 \\
(0.007)\end{array}$ \\
\hline Lynching (log) & $\begin{array}{l}0.132^{* * *} \\
(0.012)\end{array}$ & $\begin{array}{l}0.132^{* * *} \\
(0.012)\end{array}$ & $\begin{array}{l}0.130 * * * \\
(0.012)\end{array}$ & $\begin{array}{l}0.130 * * * \\
(0.012)\end{array}$ \\
\hline Black Adult Male Pop. (log) & & $\begin{array}{l}-0.002 \\
(0.002)\end{array}$ & $\begin{array}{l}0.002 \\
(0.002)\end{array}$ & $\begin{array}{l}0.002 \\
(0.002)\end{array}$ \\
\hline Majority-Black Dummy & & & $\begin{array}{l}-0.034^{* * *} \\
(0.007)\end{array}$ & $\begin{array}{l}-0.03 * * * \\
(0.008)\end{array}$ \\
\hline Post-Constitution*Majority-Black Dummy & & & & $\begin{array}{l}-0.032^{* * *} \\
(0.011)\end{array}$ \\
\hline Constant & $\begin{array}{l}3,761 \\
0.68\end{array}$ & $\begin{array}{l}3,761 \\
0.68\end{array}$ & $\begin{array}{l}3,761 \\
0.68\end{array}$ & $\begin{array}{l}3,761 \\
0.68\end{array}$ \\
\hline State Fixed Effects & Yes & Yes & Yes & Yes \\
\hline Year Fixed Effects & Yes & Yes & Yes & Yes \\
\hline State Linear Time Trend & Yes & Yes & Yes & Yes \\
\hline Population & Yes & Yes & Yes & Yes \\
\hline Observations & 1,318 & 1,318 & 1,318 & 1,318 \\
\hline R-squared & 0.57 & 0.58 & 0.59 & 0.6 \\
\hline
\end{tabular}

Robust standard errors in parentheses. ${ }^{* * *} \mathrm{p}<0.01,{ }^{* *} \mathrm{p}<0.05{ }^{*}{ }^{*} \mathrm{p}<0.1$. 